КОМПАРАТИВНИЙ АНАЛІЗ ВИТРАТ

НА ОБОРОННО-ПРОМИСЛОВИЙ КОМПЛЕКС УКРАЇНИ

ТА КРАЇН ЦЕНТРАЛЬНОЇ ТА СХІДНОЇ ЄВРОПИ

\title{
COMPARATIVE ANALYSIS OF SPENDING FOR THE DEFENSE INDUSTRIAL COMPLEX OF UKRAINE AND COUNTRIES OF CENTRAL AND EASTERN EUROPE
}

\section{УДК 355/359.07: 336.5 \\ https://doi.org/10.32843/bses.59-13}

\section{Скиба О.В.}

магістрант

Національний технічний

університет України

«Київський політехнічний інститут

імені Ігоря Сікорського»

Глущенко Я.І.

к.е.н., доцент кафредри

міжнародної економіки

Національний технічний

університет України

«Київський політехнічний інститут

імені Ігоря Сікорського»

\section{Skyba Olena}

National Technical University of Ukraine «Igor Sikorsky Kyiv Polytechnic Institute» Hluschenko Yaroslava

National Technical University of Ukraine

«Igor Sikorsky Kyiv Polytechnic Institute»

\begin{abstract}
Стаття присвячена питанням фрінансування оборонно-промислового комплексу України та окремих країн світу. Визначено та проаналізовано загальносвітові тенденції у сорері військових витрат за даними Стокгольмського інституту дослідження проблем миру. Акцентовано увагу на країнах, які входять до п'ятірки країн з найбільшими військовими витратами, визначено та охарактеризовано тенденції 2019 року. Зіставлено обсяги витрат на обороннопромисловий комплекс України та країн Центральної та Східної Європи, а саме Польщі, Республіки Білорусь, Азербайджану та Грузії, за 2012-2019 роки. Зазначено основні пріоритети фрінансування військових витрат досліджуваних країн. Проаналізовано показник витрат на національну оборону до ВВП вибраних країн. Визначено особливості розвитку їх оборонно-промислового комплексу. Сорормульовано позитивні й негативні наслідки зростання витрат країн світу на оборонно-промислову сферу.

Ключові слова: оборонно-промисловий комплекс, витрати на оборонно-промисловий комплекс, витрати на національну оборону до ВВП, фрінансування, порівняльний аналіз.
\end{abstract}

Статья посвящена вопросам финансирования оборонно-промышленного комплекса
Украины и других стран мира. Определены и проанализированы общемировые тенденции в сорере военных расходов по данным Стокгольмского института исследования проблем мира. Акцентировано внимание на странах, входящих в пятерку стран с крупнейшими военными расходами, выявлены и охарактеризованы тенденции 2019 года. Сопоставлены объемы расходов на оборонно-промышленный комплекс Украины и стран Центральной и Восточной Европы, а именно Польши, Республики Беларусь, Республики Азербайджан и Грузии, за 20122019 годы. Указаны основные приоритеты финансирования военных расходов исследуемых стран. Проанализирован показатель расходов на национальную оборону к ВВП избранных стран. Определены особенности развития их оборонно-промышленного комплекса. Сорормулированы положительные и отрицательные последствия увеличения расходов стран мира на оборонно-промышленную сфреру.

Ключевые слова: оборонно-промышленный комплекс, расходы на оборонно-промышленный комплекс, расходы на национальную оборону к ВВП, фринансирование, сравнительный анализ.

The article is devoted to the issues of financing the defense-industrial complex of Ukraine and other countries of the world. According to the Stockholm International Peace Research Institute, global trends in military spending have been identified and analyzed. According to SIPRI, global military spending reached $\$ 1.92$ trillion in 2019, it is the highest figure since 2010 , it is $2.2 \%$ of world GDP, or $\$ 249$ per person. The countries that had the largest military spending: the United States - \$732 billion; China - \$261 billion; India - \$71.1 billion; Russian Federation - \$65.1 billion; Saudi Arabia - \$61.9 billion. Ukraine ranks 35th in terms of expenditures on defense among the countries studied; in 2019 the expenditures of our country amounted to $\$ 5.2$ billion that is $20.25 \%$ more than in 2018. The article provides a comparative analysis of the volume of expenditures on the military-industrial complex of Ukraine and the countries of Central and Eastern Europe, namely Poland, the Republic of Belarus, the Republic of Azerbaijan and Georgia for $2012-2019$. The main priorities of financing the military expenditures of these countries are noted. The indicator of expenditures on national defense to GDP of the studied countries is analyzed. There are determined that Azerbaijan is one of the ten countries with a military budget $4 \%$ of GDP. Among the countries selected for analysis, Poland showed the highest rates of military spending. For several years in a row, this country has exceeded NATO's minimum military budget requirements. In Ukraine for the period from 2012 to 2019, the coefficient of expenditures on the defense industry as a percentage of GDP reached its maximum value in 2019 - 3.4\%. In the Republic of Belarus, the coefficient of expenditures on defense industry of GDP has a stable dynamics in the range of 1.2-1.3\%. In Poland this coefficient is 2.0\% of GDP, in Georgia it decreased from 3.1\% in 2012 to $2.0 \%$ in 2019 . The features of the development of their military-industrial complex are determined. The article identifies the positive and negative consequences of increasing countries' spending on military-industrial complex.

Key words: defense-industrial complex, defense industry expenditures, expenditures on national defense of GDP, financing, comparative analysis.

Постановка проблеми. Численні конфрлікти, що спалахують в усіх кінцях світу, втягують у себе цілі народи та країни. Військові конорлікти перетворились на джерело серйозних загроз як для всієї сорери міжнародної безпеки, так і для національної безпеки окремих держав, перш за все тих, які знаходяться поблизу зон конорліктів. Крім того, зростання обсягів фрінансування оборонної сфрери зменшує можливість країн спрямовувати кошти на вирішення соціально-економічних, демографічних та екологічних проблем.
Актуальність дослідження зумовлена тим, що глобалізація сучасного світу висуває на перший план саме проблеми мілітаризації міжнародних відносин, створення необхідних гарантій для встановлення довгострокового та міцного миру. Як показує світова практика, саме фрінансування національної безпеки та оборони є гарантією укріплення країни, умовою їі стабільності та ефективності економіки.

Аналіз останніх досліджень і публікацій. Проблеми національної безпеки та фрінансування 
оборонного комплексу України піднімались у наукових працях фрахівців з воєнно-економічної безпеки, таких як О.М. Олійник [1], А.Д. Лодзянов [2; 3], P.І. Сапіга [4], В.І. Мунтіян [5], М.М. Єрмошенко [6], Г.М. Перепилиця [7].

Постановка завдання. Метою статті $€$ проведення порівняльного аналізу витрат на оборонно-промисловий комплекс України та країн Центральної та Східної Європи, а саме Польщі, Республіки Білорусь, Азербайджану та Грузії за 2012-2019 роки.

Виклад основного матеріалу дослідження. Для дослідження використані дані, оприлюднені Стокгольмським інститутом дослідження проблем миру (Stockholm International Peace Research Institute). Саме цей міжнародний аналітичний центр, заснований у 1966 році у Стокгольмі (Швеція), спеціалізується на дослідженні збройних конорліктів, процесів контролю за озброєнням та роззброєнням країн світу. SIPRI надає дані, власний аналіз та рекомендації, засновані на відкритих джерелах [8].

Доцільно як розглянути щорічні військові витрати досліджуваних країн за 2012-2019 роки, так і проаналізувати обсяг щорічних витрат на ОПк відносно ВВП країн.

Як засвідчують дані SIPRI, світові військові витрати у 2019 році досягли майже \$1,92 трлн., що $€$ найбільшим значенням з 2010 року, вони склали 2,2\% світового ВВП, або \$249 на людину.

Порівняно з 2018 роком у 2019 році військові витрати збільшились на 3,6\%. У першу п'ятірку країн 3 найбільшими військовими витратами увійшли США, маючи \$732 млрд. (темп приросту у 2019 році порівняно 32018 роком становив 7,2\%); Китай, маючи \$261 млрд. (темп приросту у 2019 році порівняно з 2018 роком становив 2,8\%); Індія, маючи \$71,1 млрд. (темп приросту у 2019 році порівняно з 2018 роком становив 7,24\%); Російська Федерація, маючи \$65,1 млрд. (темп приросту у 2019 році порівняно з 2018 роком становив 6\%); Саудівська Аравія, маючи \$61,9 млрд. (військові витрати у 2019 році порівняно 32018 роком зменшились на 16,8\%) [8].

Загалом на першу п'ятірку країн припадають 62\% всіх світових військових витрат.

За даними SIPRI слід відзначити, що вперше дві країни Азії одночасно потрапили до топ-3 країн з найбільшими військовими витратами.

у Європі найбільше зростання військових витрат продемонструвала Німеччина (+6\% за рік, обсяг становить \$49,3 млрд.). Німеччина перебуває на 7 рядку, поступаючись Франції (обсяг становить \$50,1 млрд., зменшення на 2,5\%) [8]. Ha думку наукового співробітника SIPRI Дієго Лопеса де Сільви, таке значне зростання витрат на ОПК в Німеччині, як і в інших країнах-членах НАТО, пов'язане з відчуттям наростаючої загрози з боку Російської Федерації.
Досить значне зростання витрат на обороннопромисловий комплекс слід відзначити у Великої Британії (обсяг становить \$48,7 млрд., зниження у 2019 році порівняно з 2018 роком складає 2,4\%), Японії (обсяг становить \$47,6 млрд., приріст у 2019 році порівняно з 2018 роком складає 2,2\%), Південної Кореї (обсяг становить \$43,9 млрд., приріст у 2019 році порівняно з 2018 роком складає $1,8 \%)[8]$.

Україна, за оцінками дослідників, за витратами на ОПК серед досліджуваних країн світу займає 35 рядок (роком раніше вона займала 41), використавши на військові потреби \$5,2 млрд., що на 20,25\% більше, ніж у 2018 році. Військові витрати склали 3,4\% ВВП України, цей показник співставний з показником США, але нижче, ніж у РФ (3,9\%). Якщо провести порівняння з 2010 роком, то можна зазначити, що військові витрати України зросли на $132 \%$ [9].

На підставі даних SIPRI на рис. 1 представлено витрати на ОПк України, Польщі, Республіки Білорусь, Азербайджану та Грузії.

Серед вибраних нами для аналізу країн найбільші показники військових витрат має Польща. У 2019 році у Польщі на обслуговування оборонно-промислового комплексу було виділено 11903 млн. дол. США. Ця країна вже кілька років перевиконує вимогу НАТО щодо мінімального рівня військового бюджету, а в наступному році планує витратити на армію 2,2\% ВВП [10].

Основними напрямами, на які будуть витрачені бюджетні кошти, у 2021 році стануть посилення військових частин на сході Польщі, технічна модернізація збройних сил, збільшення їх чисельності, а також виконання союзницьких зобов'язань у рамках блоку НАТО. Крім того, чимала частина оборонних витрат виділена на розвиток військ територіальної оборони, підтримання кібернетичної безпеки у військовому відомстві, а також на вжиття навчальних заходів на національному та міжнародному рівнях.

Для того щоби підготувати обґрунтування для постійного підвищення військових витрат, у травні 2020 року президентом Польщі було затверджено нову редакцію Стратегії національної безпеки. У документі «найсерйознішою загрозою» для республіки абсолютно очікувано була оголошена Росія [10].

Динаміка витрат на ОПК України демонструє тенденцію до зростання протягом досліджуваного періоду. У 2019 році з Держбюджету України на військові витрати було виділено 5229 млн. дол. США, що на 62\% більше, ніж у 2012 році, а також на 20,25\% більше, ніж у 2018 році. За інформацією Міністерства оборони України, основний пріоритет залишається незмінним, отже, ним є відновлення й розвиток об'єктів інфрраструктури, закупівля, модернізація і ремонт озброєння та військової тех- 


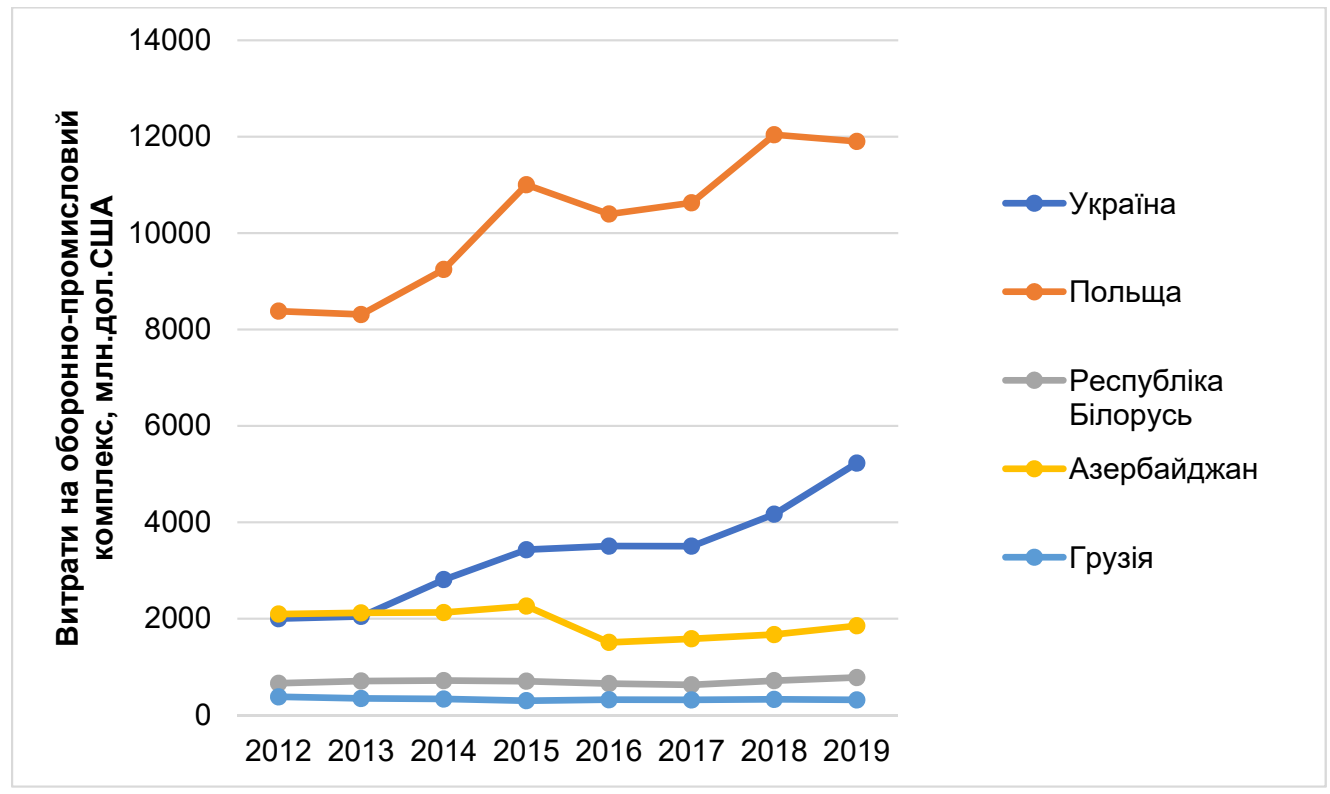

Рис. 1. Витрати на ОПК за 2012-2019 роки, млн. дол. США

Джерело: побудовано за даними джерела [8]

ніки (ОВТ), отримання необхідних можливостей, що відповідають критеріям членства в НАТО.

Щодо Республіки Азербайджан, то, як можна побачити на рис. 1, військові витрати цієї країни 3 2016 по 2019 роки мали тенденцію до зростання, хоча порівняно з 2012-2015 роками вони були значно зменшені. У 2016 році порівняно з 2015 роком державні витрати на ОПК зменшились на 66,7\%. У 2019 році цей показник склав 1854 млн. дол. США.

Показники витрат на оборонно-промисловий комплекс Республіки Білорусь демонструють стабільний рівень значень, за винятком 2016-2017 років, коли спостерігається незначне зниження військових витрат. У 2019 році країною було виділено 780 млн. дол. США, що на 8,3\% більше, ніж у 2018 році. Оборонно-промисловий комплекс Республіки Білорусь є достатньо потужним передусім через те, що більша його частина дісталася країні у спадок від СРСР. Проте слід зазначити, що серед виробів білоруських оборонних підприємств, наприклад, у сорері електроніки є декілька унікальних розробок, що не мають аналогів у світі, що свідчить про стрімкий розвиток білоруського оборонпрому. Російська Федерація довгий час залишалась основним союзником Республіки, на якого був орієнтований ОПК Білорусії. Білоруські підприємства виробляли майже 2 тис. різних вузлів та агрегатів для Росії, їхня частка становила близько $15 \%$ у російському ОВТ. Проте, попри всі наявні офріційні домовленості між РФ та Республікою Білорусь щодо тісного співробітництва у сорері оборонних технологій, ситуація змінилась після початку агресії проти України. Росія поступово почала витісняти білоруських виробників зі свого ринку з огляду на недоцільність такого стратегічного виробництва в іншій країні [11]. Одним із прикладів нової стратегії Росії можна назвати відмову Білорусі в продажу сучасних російських зразків ОВТ, зокрема ЗРС С-400 та ОТРК «Іскандер». Цей фракт змусив Білорусь розробити власний ракетний комплекс «Полонез», а також провести диореренціацію ринків збуту. Новим ринком збуту став Китай. За останні п'ять років сукупний обіг продукції ОПК між країнами зріс удвічі. Безумовно, для Мінська це додаткова можливість отримати фрінансування в умовах стагнації економіки, а для Пекіна - новий ринок для просування своєї продукції та можливість закупити новітні якісні зразки ОВТ в обхід наявних обмежень серед деяких країн НАТО [11].

За словами Міністра оборони Грузії, одним 3 пріоритетних напрямів діяльності оборонного відомства країни $€$ розвиток військової промисловості. Він також відзначив, що головною ідеєю під час фрормування бюджету є піклування про військових, крім того, посилення обороноздатності країни загалом. У 2012-2019 роки держвитрати на армію в Грузії демонстрували стабільну тенденцію з незначними коливаннями. У 2019 році вони склали 316 млн. дол. США, що на 0,9\% менше, ніж у 2018 році, але дорівнюють рівню витрат у 2017 році.

Найважливішим показником воєнно-економічної безпеки країни є рівень витрат на національну оборону у відсотках до ВВП. По досліджуваних країнах динаміку зазначеного показника наведено на рис. 2.

Азербайджан входить до десятки країн, військовий бюджет яких складає від 4\% та вище до ВВП. Азербайджан мав найбільший показник вій- 


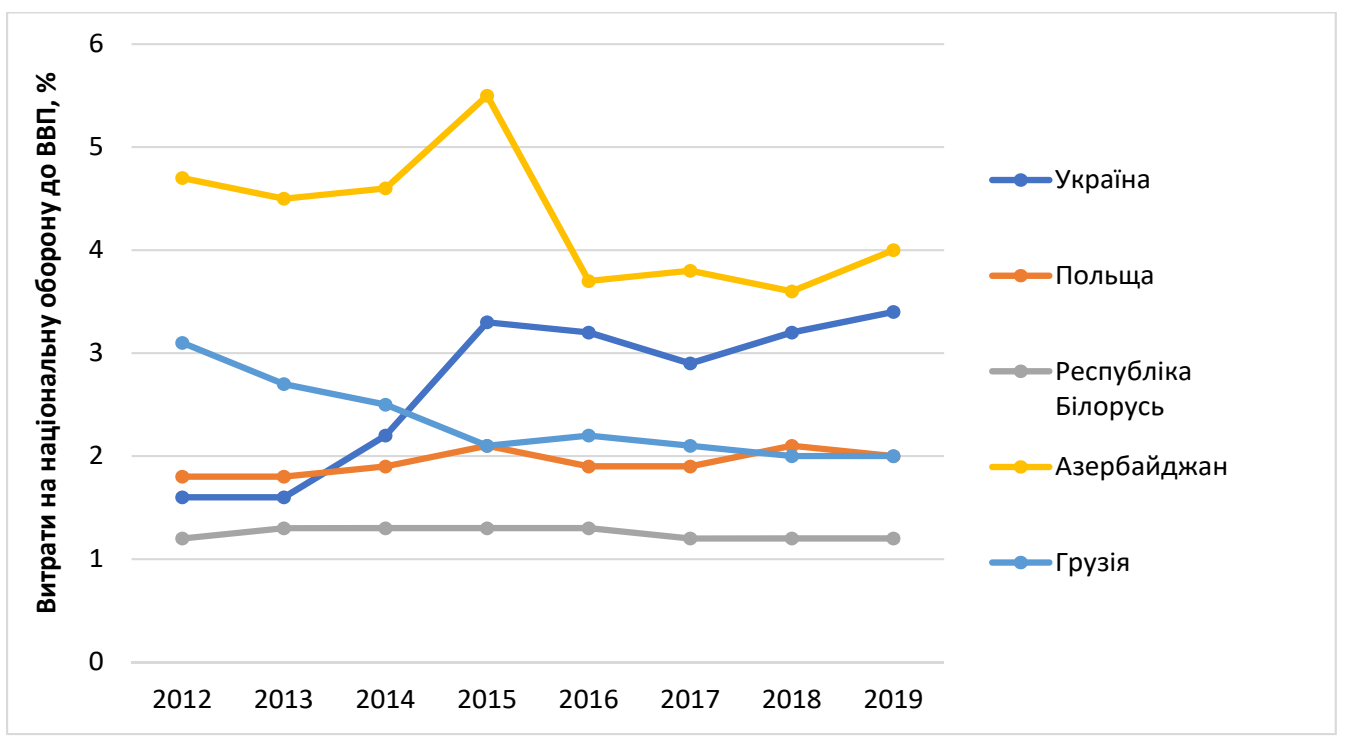

Рис. 2. Витрати на ОПК до ВВП за 2012-2019 роки, \%

Джерело: побудовано за даними джерела [8]

ськових витрат у відсотках до ВВП у 2015 році (5,5\%), проте у 2016 році було зниження на 0,67\% з показником 3,7\%, але у 2019 році він збільшився до 4\%. В Україні за 2012-2019 роки коефріцієнт витрат на ОПК у відсотках до ВВП досягнув свого максимального значення у 2019 році на позначці 3,4\%. В Республіці Білорусь цей показник має стабільну динаміку на відмітці 1,2-1,3\%. Протягом 2012-2020 років Польща збільшила показник у 2019 році порівняно з 2012 роком на 0,22\%. У 2019 році він склав 2,0\% від ВВП країни. Якщо подивитися динаміку цього показника в Грузії у взятий нами період, то побачимо, що він знизився з 3,1\% у 2012 році до 2,0\% у 2019 році.

Як ми бачимо, за останні вісім років у світі продовжує набирати обертів тенденція щодо нарощування країнами світу витрат на озброєння. Зростання оборонних бюджетів відбувається, незважаючи на загальні заяви про необхідність боротьби 3 кліматичними змінами та бідністю, потребу в розробленні нових проривних технологій лікування хворіб або виробництві чистої електроенергіï.

Розвиток оборонно-промислового комплексу для країн може виступати цілком ефективним інструментом для стимулювання економічного зростання та збільшення наукового потенціалу. Інвестиції в оборонну галузь, особливо у надсучасні їі сектори, можуть принести реальні дивіденди й посилити цивільну частину промисловості. Водночас ні тривалий збройний конфлікт (Ізраїль), ні різні обмеження чи санкції (КНР, Білорусь, Російська Федерація) не стануть серйозною перешкодою, якщо керівництво країни справді має політичну волю та бажання [11].

Хоча, на думку представників SIPRI, витрати на оборонну галузь досягли свого пику у 2019 році, оскільки подальше поширення коронавірусу у світі та відповідні заходи країн щодо подолання наслідків епідемії призведуть до масштабних негативних економічних наслідків.

Висновки з проведеного дослідження. Проведене дослідження дає змогу стверджувати, що останніми роками загальносвітовою тенденцією $€$ зростання витрат на оборонно-промисловий комплекс. Зазначена тенденція має як позитивні, так і негативні наслідки. До позитивних наслідків слід віднести підвищення рівня обороноздатності країн, розвиток підприємств, які безпосередньо входять до складу ОПК, а також пов'язаних з ними підприємств цивільних галузей. Серед негативних наслідків можна відзначити зростання напруги у взаємовідносинах окремих країн та недофінансування багатьох глобальних проблем.

Наукова новизна дослідження полягає у систематизації результатів компаративного аналізу військових витрат України та країн Центральної та Східної Європи. Подальші дослідження будуть спрямовані на дослідження фракторів, що впливають на рівень витрат на ОПК.

\section{БІБЛІОГРАФІЧНИЙ СПИСОК:}

1. Олійник О.М. Воєнно-економічна безпека України в епоху локальних збройних конфрліктів. Воєнна історія. 2003. № 2. С. 4-15.

2. Лодзянов А.Д., Ольшевський В.Й. Інноваційні підходи до розвитку науково-технічної діяльності в інтересах оборони держави. Проблеми науки. 2002. № 7. С. 11.

3. Лодзянов А.Д., Сніжко Г.Т. Воєнно-економічна безпека в умовах реформування оборонної сфери України: системний підхід до визначення критеріїв і показників. Стратегічна панорама. 2004. № 1. C. $65-72$. 
4. Сапіга P.І. Воєнно-економічна безпека в контексті логістичного забезпечення. Вісник Хмельницького національного університету. 2011. № 6. T. 4. C. 134-138.

5. Мунтіян В.І. Фінансування Збройних Сил України: проблеми та перспективи. Дзеркало тижня. 2002. № 34 (409). C. 3.

6. Єрмошенко М.М., Горячева К.С. Фінансова складова економічної безпеки: держава і підприємництво : монограсрія. Київ : НАУ, 2010. 232 с.

7. Воєнна безпека України на межі тисячоліть / Національний інститут стратегічних досліджень при Адміністрації Президента України. Київ : Стилос, 2002. 394 c.

8. Stockholm Peace Research Institute. URL: https://www.sipri.org/sites/default/files/Data\%20for\%20 all\%20countries\%20from\%201988\%E2\%80\%932019\%20 in\%20constant\%20\%282018\%29\%20USD.pdf(дата звернення: 20.11.2020).

9. Світові військові витрати зросли до десятирічного рекорду, Україна на 35-місці. Бизнес - новое время. URL: https://nv.ua/ukr/biz/markets/svitovi-viyskovi-vitrati-ukrajina-na-35-u-misci-za-vitratami-naarmiyu-ta-ozbroyennya-ostanni-novini-50084671.htm (дата звернення: 16.11.2020).

10.Попри коронакризу Польща нарощує оборонні витрати. Оборонно-промисловий кур'єр. 2020. URL: http://opk.com.ua (дата звернення: 16.11.2020).

11. Лапаєв Ю.В. ОПК: Марш назустріч. Тиждень.иа. URL: https://m.tyzhden.ua/publication/238840 (дата звернення: 16.11.2020).

\section{REFERENCES:}

1. Oliinyk O.M. (2003) Voienno-ekonomichna bezpeka Ukrainy $v$ epokhu lokalnykh zbroinykh konfliktiv [Military and economic security of Ukraine in the era of local armed conflicts]. Military history, no. 2, pp. 4-15.

2. Lodzianov A.D., Olshevskyi V.Y. (2002) Innovatsiini pidkhody do rozvytku naukovo-tekhnichnoi diialnosti $v$ interesakh oborony derzhavy [Innovative approaches to the development of scientific and technical activities in the interests of national defense]. Problems of science, no. 7, pp. 11.

3. Lodzianov A.D., Snizhko H.T. (2004) Voienno-ekonomichna bezpeka $v$ umovakh reformuvannia oboronnoi sfery Ukrainy: systemnyi pidkhid do vyznachennia kryteriiv i pokaznykiv [Military and economic security in the conditions of reforming the defense sphere of Ukraine: a systematic approach to defining criteria and indicators]. Strategic panorama, no. 1. pp. 65-72. (in Ukraine)

4. Sapiha R.I. (2011) Voienno-ekonomichna bezpeka v konteksti lohistychnoho zabezpechennia [Military and economic security in the context of logistics]. Bulletin of Khmelnytsky National University, no. 6, vol. 4, pp. 134-138.

5. Muntiian V.I. (2002) Finansuvannia Zbroinykh Syl Ukrainy: problemy ta perspektyvy [Financing of the Armed Forces of Ukraine: problems and prospects]. Mirror of the week, no. 34 (409), pp. 3.

6. Yermoshenko M.M., Horiacheva K.S. (2010) Finansova skladova ekonomichnoi bezpeky: derzhava i pidpryiemnytstvo [The financial component of economic security: the state and entrepreneurship]. Kyiv: NAU. (in Ukrainian)

7. Voienna bezpeka Ukrainy na mezhi tysiacholit (2002) [Ukraine's military security at the turn of the millennium]. National institute for strategic studies. Kyiv: Stylos.

8. Stockholm Peace Research Institute. Available at: https://www.sipri.org/sites/default/files/Data\%20for\% 20all\%20countries\%20from\%201988\%E2\%80\%9320 19\%20in\%20constant\%20\%282018\%29\%20USD.pdf (accessed 20 November 2020).

9. Svitovi viiskovi vytraty zrosly do desiatyrichnoho rekordu, Ukraina na 35-mistsi [World military spending has risen to a ten-year record, with Ukraine in 35th place]. Business - new time. Available at: https://nv.ua/ ukr/biz/markets/svitovi-viyskovi-vitrati-ukrajinana-35-u-misci-za-vitratami-na-armiyu-ta-ozbroyennya-ostanni-novini-50084671.html (accessed 16 November 2020).

10. Popry koronokryzu Polshcha naroshchuie oboronni vytraty (2020) [Despite the corona crisis, Poland is increasing defense spending]. Oboronno-promyslovyi kurier. Available at: http://opk.com.ua (accessed 16 November 2020)

11. Lapaiev Yu.V. (2019) OPK: Marsh nazustrich [OPK: March towards]. Week.ua. Available at: https://m.tyzhden.ua/publication/238840(accessed16November 2020). 